\title{
COMMENTS ON THE FUTURE OF THEOLOGICAL EDUCATION IN AFRICA *
}

John S Pobee

University of Ghana

\begin{abstract}
7) This article is based on a paper the author read in 1986 at a conference at the University of Ghana. This conference was convened by the West African Association of Theological Institutions and Programme on Theological Education of the World Council of Churches.

The article deals with a wide range of issues, from the practical (such as staff, money and logistical matters), to the theoretical. The key concept is that theology is not only a matter of knowledge, but also of wisdom. Special attention is also drawn to Africa's need to reflect more-closely on the plural character of its society, and it is suggested that 'inclusiveness' ought to be a fundamental guiding principle.
\end{abstract}

For many people the University Department of Theology represents the work-place of theology, since it is a scientific discipline like any other discipline in the humanities. But it is important not to stop there, for theology is not only knowledge, but also wisdom by which we live. Islam, for example, is as much a faith as a lifestyle. Indeed, the word means submission to Allah. Christianity as a faith is not only learnt, but also done. Jesus, in his style of teaching, associated the disciples with him in his work, so that they participated in the work, and thus entered the deeper mysteries of the faith. In the post-Enlightenment culture of the world this last point is debated, or even sometimes forgotten. But the story of the University of Leiden in Holland bears out the original intention of the scientific method. That University was set up in 1573 after the liberation from Spain, with the declared intention of training pastors of the Reformed Religion. The implicit idea was that the scientific study of scripture can or should guarantee the freedom of the Word of God over against its domestication by Rome and other churches, as well as by spiritism.

\footnotetext{
* Prof John S Pobee is Ghanaian and an Anglican. He is on leave of absence from the University of Ghana, to serve as an Associate Director of the Programme on Theological Education of the World Council of Churches, in Geneva.
} 
Therefore, theology,- scientifically studied, was not supposed to be a kind of mandarin's art, but a service tool to the people of God's faith and witness in a real world, in this time and place with all their hopes and fears. Theology is the reflection on and articulation by real human beings, of their experiences of the self-disclosure of God in this world. It is reflection; it is articulation. But, as the English adage goes, 'the proof of the pudding is in the eating.' The value or wisdom of any action can be discovered most fully by actual experience. So, in addition to reflection and articulation, we must add experience and life-style that bears out the claim.

For many people today theology is Christian theology. That is in part a relic of the arrogance that went with the idea of Christendom and the Crusader mentality. For the self-disclosure of God has taken diverse forms. Besides Christianity, Islam, African Traditional Religions, Hinduism, etc, contain self-disclosures of God. So the word theology may not be limited to the articulations of Christians. But for the purposes of this paper we shall limit ourselves to Christian theology. Even so, let me emphasize that Christian theology cannot be done in isolation, without engagement with other religions in the African context. Christian theology is concerned with interpreting the Christian faith tradition for faith and praxis in the contemporary world and society. But in a multifaith nation, this must relate to other faith

traditions. That is why most African universities have gone in for Departments of Religious Studies, where also every effort is made to interpret the life and grasphold of the religious realities which motivate its avowed adherents. While on the subject, let me add that theology does take the form of not only discourses or treatises, but also of drama, song and oral articulation.

\section{African context for theologizing}

Earlier mention was made of the fact that God's self-disclosure is never a-cultural. So let us attempt in broad sweeps to delineate some of the features of that" real world of Africa in which theologizing and theological education take place.

(a) North Atlantic captivity and inheritance

First, whatever else may be said, Africa is in some kind of North Atlantic captivity. That is one consequence of the colonial history of most African peoples. One front of that colonial history is the appearance of Christianity in Africa south of the Sahara, except perhaps Ethiopia. And what the missionaries brought was what they knew.

Therefore, the churches in Africa are naturally modelled on the North Atlantic churches in theology, in concepts and practice of ministry, in ethics, in liturgy, in spirituality, etc. And so, in the words of Bishop Prince E S Thompson, 'we seem now to be in the watershed of two difficult eras - the old colonial era now coming to an end, and a new era in which Africa and all things African are dipped in the waters of Baptism to emerge cleansed and purified and productive according to God's grace.' The Atlantic captivity is a fact of history and in some ways not totally eradicable. But since it was not an a-cultural heritage, there is need to evaluate critically and 
recontextualize that heritage so that the Word may become flesh in Africa too. So on this voyage the key signpost is recontextualisation. 1 There is a need for a new skenos (Greek: tent) which is African, and communicates to homo africanus and theology like theological education becomes an instrument of skenosis, a tabernacling of the eternal word of God in Africa too (cf John 1:14). In this regard it is a matter of grave concern that in many places there is a predominance of expatriate staff among theological educators, e g Zambia, Malawi. How can non-Africans be expected to do a thorough job of indigenisation? A necessary part of recontextualization is a moratorium on expatriate staff, and that the plant be nurtured and watered by indigenous hands.

Theological education does not evolve in isolation. The system of education in Africa reflects the diverse structures and assumptions that were inherited with the diverse colonial systems. For example, in Francophone Africa, following the rigid separation of Church and State, theology was not usually a discipline in the state university; it was done in a separate church institution with all the financial implications on the churches. On the other hand, in most of Anglophone Africa, theological education was one of the subjects on the university's curriculum, and paid for by the state, as well as religious education on the pre-university curriculum. This latter example raises very interesting questions. Can the basic theological education be done in these university departments, so that the church seminaries may concentrate on pastoralia, practical theology, liturgy? And if that is to happen, should the university departments not be more sensitive to the needs of the community of faith? And how does that affect the matter of university departments being forced to be assimilated to other university scientific disciplines and in the process live it real that theology is at once knowledge and wisdom by which to live? How do the theologians help the churches in Africa, whom they serve, to shed their colonial image and trappings, so as to commend themselves as true agent, servant, instrument and sacrament of the Kingdom of God in this world? Should the graduate studies not be left to the university departments rather than every seminary attempting to mount graduate studies with inadequate resources? The theologian also needs to remember that the enlightenment preoccupation with scientific method, when put in the African context, can make the discipline and Christianity look colonial. And therefore, "the scientific method itself has to be tested in the context with a view to making it a relevant tool?

\footnotetext{
1. There are some words that need to be distinguished: restoration, revolution, reformation and, renewal. To reform is to give another form, to restore to an earlier better form and to shape anew something that has been deformed. It implies a kernel which is to be given a new form, which has a transitory validity. Restoration is a lethargic aiming at the maintenance of a system, a revival of an outworn system. Revolution is a violent overthrow of values or authority, a chasing after the new in a doctrinaire, fanatical fashion without piety to the past. Renewal is to seek to preserve the continutity of

|l historical development, while at the same time seeking new forms appropriate to the new times. This

- involves radical reinterpretation and re-evaluation of received forms and structures for a positive, creative encounter.
} 
One more item of the North Atlantic captivity, of scholarship - liberalism. The North Atlantic has been deeply influenced by the liberal philosophy. That philosophy has among other things two characteristics:

(i) A separation between church and state. And what was said above about what obtains in Francophone Africa, is a concrete example of that philosophy transplanted in Africa.

(ii) It also distinguishes between the individual's faith and the life of the people. These in my view go against the grain of the authentic biblical faith which has a holistic view of life. But that aside, in Africa there is ample evidence in traditional and contemporary society that one of the springs of political and economic life is religion. Thus, in the African context, religions can no longer be relegated to the limbo as the business of the clergy, and in that context, the separation between faith and life, individual conscience and social process are false distinctions. In any case, many conscientious Christians are living their faith in secular life, for which they need to be equipped.

It is my submission that those two aspects of the liberal philosophy have no place in theology and theological education in Africa ${ }_{\text {or }}$ are unexamined assumptions on the Afrrican scene. Relevant scholarship that helps people to understand and cope with their situation and life in the light of the Word of God, is what is needed.

IThe North Atlantic captivity of the churches in Africa is manifested inter alia as the persistence of denominationalism. The strange thing is that the historical reasons for the denominationalism in Europe and America are not a first order experience of the Africans. Indeed, such denominational disorders are transcended by family ties which still hold; for in the one family, nuclear or extended, there may be diverse faith traditions and denominations, and that does not exactly disturb their living as a family. In other words, most of the time denominationalism is an irrelevance. And yet, because of history and the psyche of a daughter vis- $\grave{a}$-vis a mother church, theological education is largely done denominationally. There is every evidence of the ossifying influence of denominational teaching. So African theological education needs to face head-on the persisting denominationalism, which is not only wasteful, but also obfuscates the Christian message and ministry of reconciliation.

The inherited education system had an implied theory. Education, particularly university education, was, under the British colonial influence, to produce an intellectual reservoir schooled in British secular, social life, and capable of performing responsible tasks. This meant the curriculum was primarily geared neither to the needs of the church, nor of the African society. Today we can say that theory has served its day, and that the need is to produce an intellectual reservoir that can analytically address the aspirations and problems of the African context. And in my view context is not only the culture, but also the socio-political realities of the people.

Theological education in Africa was started by the mission boards of the so-called mother churches. They designed it after the fashion of what they knew in the north; they paid for it, for the running costs, the salaries of staff and the maintenance and 
allowance of students. The staff were largely northern. Naturally then, what evolved was a carbon copy of what obtained in the north, and not always exactly relevant to the African context. Now that African nations are politically independent, and the churches are autonomous, the picture has not changed much. There may be an African principal, but the business continues as usual. A tragic comedy is that these Africans in the saddle continue to perpetuate things that have been abandoned in the north itself. Autonomy has not necessarily meant the wiping out of North Atlantic captivity.

Theological education in Africa should address the matter of its North Atlantic captivity and free itself so as to be authentic in that region, and be able to address the hopes and fears of its region. Therein isexcellence determined.

(b) Africa the new centre of gravity of Christianity

Second, if the North Atlantic was once the centre of gravity of Christianity, today that centre of gravity has shifted to the south, Africa included. Not only is the church growing very fast there, but religious life is also most vibrant. It is an axiom that the theology and church life that matter are those where the faith is really alive and buoyant. So the issue at stake is not only theology for Africa, but also what Africa owes to the church universally and the future of world Christianity. The African church needs to emulate the example of Africa north of the Sahara, whose imprint on Christian theology has remained through Augustine of Hippo, Cyprian of Carthage, Tertullian, Clement of Alexandria, Origen, etc.

If church growth is that tremendous, who will train the requisite number of foot soldiers of the kingdom? The current assumption and the style of theological education reflects slow growth vision which is irrelevant to the African scene. So the fact of high growth rate is a matter of urgent concern for African churches and theological education.

\section{(c) Pluralism}

Third, the church lives in a plural society. And so, theology is formed in a plural context. There is cultural and religious pluralism. But equally important is Hecclesiological pluralism. In this regard I wish to mention two groups in particular: $\beta$ African Christian Independency (ACI), and those who call themselves 'Evangelicals.' These are brothers and sisters in the faith and travel in one boat with us in pursuit of faith and witness of the church. African Christian Independency represents among other things a cultural renaissance, a protest against the North Atlantic captivity of the gospel, as well as the desire to experience the Spirit of God as real power today, as of old. They represent a way of apprehending reality which is more authentically African than the very foreign expression of reality represented by the so-called historic churches. The 'Evangelicals' are operating in Africa in a big way. For some people they represent an up-hill task to human judgement on the discussion of biblical topics. Whatever judgement we may make of them, they are brothers and sisters in the faith and should be seen to be brothers and sisters in the faith, whatever the theological differences. It was the Romans who said quot homines tot sententiai, $\mathrm{i}$ e as there are human beings, so will there be opinions. Diversity of 
opinion is part of our human condition. The Akan of Ghana say 'even twins can differ,' or adwen nyina nsee, that is, not all minds are the same. To refuse to accept pluriformity is to enforce schism, and to practice intolerance which marks religious

wiperialism. Neither of these is consonant with the Christian emphasis on reconciliation.

The long and short of this pluralism - cultural, ethnic, religious and ecclesiological is that theological education in Africa needs to be more than conscious of the context of pluralism which is all to be brought under the sovereignty of God through Christ. This already sets an ecumenical agenda, church as well as human. So we need to explore in our respective regions of Africa the structures that will enable this ecumenical agenda to be realised. In this regard the dialogical method is nonnegotiable in theological education. In the 1960s Joint Theological Colleges were seen as tool for this ecumenical goal. But somehow it does not seem to be doing the trick; most ecumenical institutions are in trouble for financial reasons as well as for reasons of inter-denominational rivalry. Further, the resurgence of denominationalism is in part due to the fact that as traditional societies break up, especially in the cities, the churches, often tribally based, take their place as little tribes with little-tribal heads, and thus churches become the focus of faith and tribal solidarity.

My prognosis is that too much weight was put on the institutional framework; we should rather put emphasis on people, persons of faith who are fired by the ecumenical vision Important as institutional framework is, it not infrequently gets bedevilled by politics and officialdom. It is people in dialogue, in eyeball to eyeball engagement, who see the beauty of the mosaic of pluralism that God has created.

In an Africa plagued by divisions - tribal, racial, gender, etc - theological education cannot become an accomplice or accessofy in the resurgence of any form of sectionalism. Its rale is to foster wholeness of peoples and societies of the.church as of the state; it shoula toster an inclusive community. Inclusiveness may then be yet another guiding principle of theological education and a sign-post of the theological journey.

While on inclusiveness, let me mention women. Theological education has been dominated by men. And, of course, that is all mixed up with cultural factors on the place of women in society as well as a church that is in the grip of patriarchal models. As one looks at Black Africa, even if many women have read Theology at the university level, they are hardly in evidence in top positions in church or in the seminary. Very few university departments of Theology or Religious Studies in Black Africa have women on the faculty. And this happens when in other areas of life such as commerce, civil service, teaching, etc, women are doing unquestionably well. Surely there is need for conversion in theological circles to enable the inclusion of women. To me the theological issue is whether women also bear the image and likeness of God and if so, their inclusion, like any other group, is a must and they will bring the necessary complementary insights of women to articulating the experience of God's self-disclosure in the world. 


\section{(d) African culture and realities}

Fourth, if the Church is not an island unto itself, and if it is inextricably bound up with the society and world, the contemporary issues of society should engage theological education:

(i) Context of poverty with its diverse indices leading to a sense of hopelessness in people. How does theological education equip the people of God to give meaningful and relevant hope to people who have no reason to have hope?

(ii) Situations of political instability marked by injustice, abuse of human dignity, etc. And so, how does theological education contribute to the search for political stability and peace, justice and human dignity? It is the task of theological education to equip people to reflect theologically on the social, political and economic circumstances of their context.

(iii) African world-view which is taken in with mother's milk and therefore, can never be wished away, even by the most rabid iconoclasts. Earlier missionaries sought a complete break with traditional world-view. With hindsight we can claim it was not a sound approach. Joseph Ephraim Casely Hayford (1866-1930), one of the leaders of the Aborigines Rights Protection Society (founded 1897 in the Gold Coast) described the average product of the mission school as a 'black whiteman who is a creature, a freak and a monstrosity. ${ }^{2}$

Today there is not much dialogue between Christian leaders and the traditionalists. Thus another guiding principle for theological education should be openness and genuine dialogue with the world in which the theological eđucation is done as a service to the people of God in their ministry to this world. Theological students then should be equipped with social science methods to enable them to face the cultural realities of contexts. But a positive attitude to African culture does not mean the suspension of critical appraisal of it in the flux of history. It is also a call for new symbols which make for the liberating influence of God's self-disclosure as the one who saves in one's own context, while pointing to the transcendent.

\section{House-cleaning}

If theological education is to be relevant, it has to set its own house in order, as well as help the church it serves to set its house in order. Three areas are important in this regard.

\section{(a) Theological scholarship}

There is need for a whole conversion experience with regard to the nature of theological scholarship. It is theology and it is education. Any distinction between theology and theological education is misleading. It is education or formation of a

2. Hayford, J E Casely 1911. Ethiopia Unbound. London: Phillips, 10. 
community of faith for the dynamic survival of the faith. It is a science in the sense that it seeks by investigation and questioning to reach ordered knowledge about God's self-disclosure in a plural world. But it is also about commitment to a faith and to the world created by God. Herbert Zorn writes: '...theological education is education, commitment is no substitute for competence. Academic excellence, technical proficiency and breadth of experience are necessary components of theological education. The specific problem of the third world theological education concerns the standards by which these components are measured, as well as the minimum requirements by which they can be achieved. Precisely at this point, the questions of "hybridizing the transplant" and of "search for native plants" arise. Standards for evaluating new patterns and methods ultimately have to be found within the context, whatever reference is made to Western standards.' 3

Let me add that it is not possible, and indeed it is undesirable to produce a blueprint for something that must be a dynamic process. At a later stage I will attempt to address the structures of theological education. So I must turn to the church which is served by theological education and scholarship.

(b) The church

All too often the church is thought of in terms of an institution and therefore, often in terms of its structures, the institutional church. But important as it is, the church is an instrument, sign and sacrament and servant of the kingdom of God, the marks of which are love, compassion, truth, holiness, justice-righteousness, unity, freedom, faith and hope. Theological education, like the church, serves that kingdom. That is why theological education should aid the people of God to develop commitment to those signs of the kingdom. That is what theological excellence consists of. Theological education should help the people of God to develop a clear vision of the shape of that kingdom in today's world and in Africa in particular.

Since that kingdom is not the preserve of Christians, the Church must be sensitive to the pluralism of the society. How do we proclaim the kingdom in a world in which there are Muslims and African traditional religionists? This means the church's vision of the kingdom can never be so final that it cannot be revised. So theological education should help create people of God who are at once humble and committed to the kingdom.

If the church is to get the right perspective on theological education, it must itself seek prayerfully to be instrument, servant, sign and sacrament of the kingdom. The image of the church that Africa has inherited is very northern. That image has been influenced by concepts of Christendom and, therefore, a church that is marked by power and grandeur, hugeness, an impregnable fortress set four-square against the secular world, a church that commands. In short, it is like Solomon's temple. That image has had its day and its strengths and weaknesses. But 'we are discovering afresh these days that the Good News of the kingdom is primarily proclaimed to the

3. Zorn, Herbert M 1975. Viability in context: the theological seminary in the Third World - seedbed or sheltered garden? Bromley: Theological Education Fund, XI. 
poor and by the poor of this earth and that therefore, the church has to be in solidarity with the poor and thus become the Church of the poor.' 4 If that is so, then we can no longer, and particularly in Africa which is proverbial for its poverty and issues of justice, continue with that image of the church as Solomon's temple. What we need is a church that lives kenosis, self-emptying, a church that is like Abraham's tent where God dwells, a pilgrim people of God making their pilgrimage of faith throughout history, time and space. And Amirtham continues: 'This will have implications for how we learn and teach in our theological programmes. We need a kingdom-oriented curriculum. This will provide insights for how we build up communities of theological education, communities that identify themselves and struggle with those who seek justice, communities where students and teachers can learn together, communities where creativity and freedom are fostered, communities where theological grappling and spiritual struggling are integrated' (ibid).

\section{(c) Ministry}

The subject of ministry in my view is one area where we see most slearly how gospel and culture are inextricably bound up. When we have made avowals of the threefold ministries of apostles, bishop/elder, deacon, we will also have to admit that the exact shape of each of these is influenced by culture and other context. For example, there is no denying that the image of a bishop in ecclesia anglicana has been accommodated to that of an upper-middle-class English gentleman. And in most cases, they turn out to be representatives of power and authority in the church and state as well as conservators of tradition. The relevance of this model of ministry to God's mission to a continent which is noted for poverty on a large scale, and injustice self-induced or inflicted by the outside world and the pluralism of faith traditions, has not exactly been worked out, or at best leaves much to be desired because the minister is at the moment a carbon copy of the minister from Europe. If theological education is to have its perspectives right, it needs to have clarity on the nature and shape of the ministry on the African continent.

Two things I venture to say. First is the lessons we truly take from ministry in African Christian Independency which have taken seriously the African context and the traditional concepts of ministry. A minister in these two traditions is not just not a ritual specialist; a minister is a person of power. Such power is most evident in acts of power done in the Spirit e g healings and exorcism. Besides, the minister is a general factotum and kind of lineage head to whom people come for advice and the resolution of their problems, material and spiritual. That is what makes him most influential and makes his ministry attractive and respected and relevant. Can theological education equip people for such expected ministry?

Down the years, particularly of the missionary era, the historic churches have lost sight of the healing tradition which Jesus practised. That Jesus tradition is on a net with the traditional African experience in which healing is a function of religion and as such African Christians are dissatisfied with the departmentalisation and differentiation by which moral and spiritual healing are provided for sacramentally, but miraculous cures are associated with shrines and saints. Shorter, an anthropologist, a theologian and White Father missionary in Eastern Africa writes as 
follows: 'The Church's own sacramental life appears to make little impact, or at least to have little apparent relevance to the multi-dimensional needs of the new Christians in the sphere of suffering and relief from suffering. Existing liturgical and canonical forms make it difficult to incorporate the new healing gifts and healing traditions that are springing up, and there is a real danger of heterodoxy or even schism.' 5 There is no way relevant ministry in Africa can ignore or be deficient on healing being a function of religion and, therefore, of ministry. But healing ministry is a charisma and not everyone has it. So we plead for the recognition of diverse ministries, complementing each other.

To put it another way, we need to recapture the biblical insight that there is one ministry, that of Christ which takes diverse forms. 'There are different kinds of gifts, but the same Spirit. There are different kinds of services, but the same Lord. There are different kinds of working, but the same God works all of them in all persons' (I Cor 12:4-11 cf Eph 4:11-13). The ministry is also a teaching ministry. Therefore, the ministry of the Word is important. But it is not the only ministry; it is one alongside several. The priestly role is an important part of ministry, but not the only one. We need a sense of the composite nature of Christ's ministry.

But this has implications for the selection criteria of candidates for training. The criteria should not be mainly academic, as it tends to be today; we should also look for signs of the charisma of leadership - natural leaders whose life-style shows signs of the kingdom values, in short, spirituality.

Second, contrary to usual claims, there is not one form of ministry. I do distinguish at least four types: (a) Church-related occupational roles e g clergy, deacons, catechists and other religious functionaries. These need academically based equipment for their pastoral roles e g counselling techniques, psychology of religion, pastoral casework, fundamentals of socio-economic circumstances which form the context of their ministry. (b) Education related occupational roles as those who will teach religious knowledge in school. They need broad, bias-free, academically sound and up to date knowledge of the religious diversity and general development of humankind. (c) Academically oriented occupational roles and (d) more diffused group of occupational roles e $\mathrm{g}$ those related to media of mass communication, welfare work, adult education. But let me add here that developing African theologians especially in biblical studies, is a key to the future of a well founded African theological education.

If we take these distinctions seriously, then ministerial formation must have different forms. Curricula must be designed for the different types of ministry. No longer may we have one curriculum for all ministries.

Furthermore, in my view, the four distinctions in ministry point to a very important point. All too often people talk as if ministry is only the full-time ordained ministry.

4. Amirtham, Samuel A 1986. A vision for theological education in Africa, in Ministerial Formation 35, September, 9 .

5. Shorter, Aylward 1985. Jesus and the witchdoctor. London: Geoffrey Chapman/Orbis, 17-18. 
But we have to face in addition to lay ministry, what is variously called 'workerpriests,' 'supplementary ministry,' 'non-stipending ministry,' 'dual-role ministry' and 'tent-making ministry.' They have a legitimate place in developing the full strength of the ministry needed to cope with the ever-increasing population of the people of God in Africa. Unfortunately, as did happen in Zambia, the full-time priests reacted in a hostile manner to non-stipendiary ministry partly, if not largely, because the latter did regular jobs which gave them esteem and financial status in the eyes of Christians.

Again, if ministry belongs to all God's people, not only the ordained, then theological education programmes must make provision for the training of those who may not be ordained. Churches are reluctant to train such persons or if they do, it tends to be an inferior type of training. But if the unordained among the people of God have a ministry that in fact goes far beyond the church, i e in the factory, in the village, in politics, then their training is a proper responsibility for theological education.

Furthermore, if ministry belongs to all God's people, and if ministry is for equipping all God's people, then the people of God must have a hand in setting and realizing the agenda of ministerial formation. Let me repeat the concluding remarks of John Macquarrie in this volume. He draws attention to co-theologizing, '...thinking deeply together about the meaning and implications of Christian faith in the modern context. Bishops have a special responsibility for getting such thinking going; for they know the needs and mood of the church and must enable and guide the dialogue. Theologians have the responsibility of bringing the treasures of their learning out of the study to the service of the church. Both bishops and theologians need wisdom and knowledge of the lay people if their thinking is to make an impact where it is needed.' Thus theologizing must be done in community and we must eschew our fond individualism in its manifold manifestations.

Let me draw attention to a peculiar creation of Africa vis-à-vis ministry. I refer to the catechist or, in some traditions, the evangelist who in my estimation is the unsung hero of African church history. In 1945 Bishop John Aglionby, the third bishop of Accra, Ghana, wrote of the catechist as follows: 'It is the catechist who had to teach them (the people of God, especially in the villages) to worship and how to pray, and often it is only after years of patient teaching and the example of Christian life lived among them that one by one lives are changed, souls are saved, a church built, a school is opened and the seeds of our holy religion are sown and fostered.' 6 Thus the catechists have been the real agents of the kingdom in the villages. Curiously they are not canonically recognized and hardly any attention is paid to their training, despite the avowed concern for orthodoxy. At best their training is haphazard. Theological education must not be left only at the level of the pastors-tobe, but should also involve the catechist, the vital and critical arm of ministry.

Thirdly, since theological education is a tool of God's mission through the church's mission in the world, plural as it is, theological education must have a missiological

6. 1945. Golden Shore, Vol X No 2, January: 22. 
goal. Sam Amritham sums it up beautifully: 'Theological education must equip the churches to discern their mission which is part of God's mission in every particular and special context. In Africa, some aspects of that context are very clearly marked. The poverty of the people, the pluralism of their faith and the struggle for human dignity unquestionably form an essential part of the mission of the church in their continent, and so form a primary concern for ministry and ministerial formation. Theological education has to help the churches.to understand this mission and be actively committed to it. ${ }^{7}$ An emphasis on church evangelism is a corrective to the seeming inability of the church to teach its members their individual as well as their collective responsibilities as Christians. The concern is how we learn to witness as a people of God and dynamize people to be witnesses to the good news of Jesus Christ. In this regard the preparation of handbooks and the like for general readers which may lead them to grasp the implications of their faith, are important assignments. I refer to study guides for self-instruction and to be a basis of discussion. For example, in a nation searching for national identity and ideology, political ethics from religious perspectives is needed badly, and that, from very early on in their youth.

\section{Structures of theological education}

I understand structures to refer to the various functions constituting the framework in which a system operates e $g$ essential services, the role of the church, the government, the people of God, professors, curricula, etc. Needless to say, this is a tall order. But let me make some comments.

Firstly, if theology is a service tool to the church, the people of God, then the people of God must be involved in the process of theological education. Most of the profoundest things I know about life and people's questionings about the meaning and purpose of life have been learnt from the fisherfolk on the beaches of Cape Coast and Accra, Ghana. They may not have book knowledge, but they understand life and they have wisdom. Their questionings, their hopes and fears become the raw materials on which the theologian, realized or in process of formation, reflects in the light of God's Word. In other words, the people of God should help in the formation of the theological agenda; at least their experiences of the self-disclosure of God has a place in the formation of the theological agenda. To put it crudely, the structures of theological education should be democratized. And I would want to believe that when they feel part of the process, they will be motivated to make contributions, financial or otherwise.

Secondly, in talking of the democratization of the structures of theological education, one is not arguing for a free-for-all situation; the church hierarchy has a special role, as accredited leaders of the people of God. If the church has a magisterium as the authentic guardian and interpreter of the full doctrine of Christ, obviously the church's hierarchy must have a special place in the discharging of that magisterium,

7. Op cit, 9-10. 
although the Vatican II document Dei Verbum subordinates the magisterium to Scripture and tradition. But as Archbishop Makhulu puts it, the church leadership needs to take ownership of theological education in the sense of being mentors, facilitators and enablers of theological education. They should also be putting their funds where their mouth is. This owning of theological education by the churches through their leaders is rooted in the conviction that 'theological education is our nerve centre and (that) our willingness to shoulder it is an indication of our maturity in Christ' (Bishop Prince Thompson).

Thirdly, maditionally the curriculum has four parts: (a) Bible and the necessary language skills; (b) Studies in church History and Tradition; (c) Studies in Theology and its various forms; and (d) Studies in the practice of the arts of ministering. These are good insofar as they go. But there is a fifth point: the world in which the church and theology live. However, what is needed is an integrated approach to the four, rather than have them be in separate compartments. Again, the study of these should not be just the acquisition of knowledge and information. Rather knowledge and availablility of information are to be seen as pre-requisites of involvement and participation. So the study should seek to motivate student and staff to involvement and participation in the faith. Intellectual freedom is a necessary quality, though that is no warrant for careless rushing after every gush of teaching. But above all, we need to break away from the reliance on Western expositions to have actual doctrinal and biblical expositions from the African serspectives $_{\text {s }}$ As the body of knowledge grows bigger and bigger, fragmentation of cognate disciplines becomes a real danger. Of course, such fragmentation was intended as a kind of division of labour and mutual supplementation. In a recently published inaugural lecture from the University of Cape Town, Professor John de Gruchy comments as follows: 'When the theological task is conceived of as a hermeneutical process, that is, the retrieving of the tradition in the present, then the theologian discovers that all the disciplines necessarily come together and function as a whole. Indeed, it might be argued that the theological task understood in this way provides the other disciplines with their reason for existence, just as they provide the theologian with the resources without which his or her task cannot be undertaken., 8

Curriculum does not arise in the abstract. Let me suggest that theological curriculum is related to or spawned by the context or social realities: the wider society which we believe to be also part of God's creation and for which God's sovereignty is claimed; the academy; and the church. The emphasis in each of these constituencies will differ. But whatever the emphasis, certain things will always bo constant. For example, insofar as its agenda is concerned with the wider socicty, theological curriculum must include the social sciences as a tool for understanding the society with which theology seeks to communicate. But it also means theology is estopped from becoming idealistic constructs of academic abstraction and from talking to itself only. Again, insofar as theology belongs to the arena of academy, it

8. De Gruchy, John 1986. Doing Christian theology in the context of South Africa or, God-talk under Devil's Peak. University of Cape Town, 11. 
has to be scientific and must insist on rationality, critical in exploring of the traditions of the faith and the social context. And yet insofar as Christian theology is an aid to the church, it also must always set the transcendent before people. De Gruchy writes: 'It ( $\mathrm{e}$ theology) borders on the poetic in its imaginative constructions where symbol and metaphor, whether in words or worship, are the appropriate means of expression. It encompasses the rigours of the historical critical method with the concern of aesthetics, to provide symbolic resonance and coherence between the history of faith and its contemporary restatement. Such methodology has its parallels in other disciplines which are equally eclectic and their use of sources, imaginative in their symbolic constructions and, inevitably committed in their pursuit of truth.' 9

All that has been said under curriculum points us in the direction of ecumenical formation, i e the people of God, particularly those in leadership positions, should be so trained as always to have sensitivity to the ecumenical goal of mission. The formation should give this exposure to the oikumene.

Fourthly, the style must be one which consciously attempts to integrate knowledge and experience. In other words, the style should be action-reflection, practice-theory, academic-applied and classroom-field experience. But, above all, it should be marked by and rooted in worship. If theological education is about reflection, articulation and experience of God's self-disclosure in the world, then it is an engagement with the holy, the mysterium tremendum et fascinosum, that mystery which is great and awe-inspiring. Such an engagement provokes worship; it provokes the response 'my Lord and my God.' In the earliest community the traditions of the church were preserved and transmitted in their worship, so that the earliest community was a worshipping community. It is in worship that we are able to enter into and understand the deepest mysteries of God. Worship is one aspect of spirituality which is at once a goal and a concomitant of theological education. The apostle Paul writes to the Church of Corinth as follows: 'The Spirit searches all things, even the deep things of God. For who among men knows the thoughts of a man except the man's spirit within him? In the same way no one knows the thoughts of God except the Spirit of God. We have ... received the Spirit of God, that we may understand what God has freely given us ... The man without the Spirit does not accept the things that come from the Spirit of God, for they are foolishness to him and he cannot understand them, because they are spiritually discerned' (I Cor 2:1014). What this means is that theology that is devoid of spiritual formation is a contradiction in terms. Relevant and convincing theological education is one that is shot through and through with spirituality which is a quality of life.

Let me briefly return to the one element of spirituality mentioned earlier, worship. In my experience, conflicts arise over worship. Therefore, the search for relevant and meaningful symbols of worship, especially in terms of the forms and symbols of worship is at the heart of the worship of the one God, Father, Son and Holy Spirit and of an ecumenical vision. That search for symbols of worship should be a

9. De Gruchy, John, op cit, 8. 
preoccupation of theological education. In Ghana the Anglicans love to refer to a theological educator called Fr Bernard Clements. When he died, Bishop Aglionby paid the following tribute to him: 'What they (i e native clergy) needed was a clear and definite knowledge of the teachings of the Christian faith so that they could take a true and living message to perplexed and hungry souls ... He (Fr Clements) showed his men (students) how to worship God in the beauty of holiness, to draw out what was best in African customs and ceremonies and to adapt and ennoble to the worship of God those very things which made their appeal to the African mind.' 10 Thus theological education must serve an indigenized form of worship which feeds an authentic deep spirituality of the students as of the totality of the people of God. Thus they will understand the deep mysteries of God on which they reflect and which they try to articulate.

To date, institutions, systematic pedagogy and established programmes of training have been emphasized. There have been three particular expressions of it in the University Departments of Theology, the Seminary and the Bible School. Let us proceed to these to make brief comments.

\section{Departments or Faculties of Theology}

Most of Anglophone Africa inherited the British tradition that theology was the queen of the sciences and, therefore, was on the agenda of University education. Some called it Theology, other called it Divinity. And as it developed in Africa it was a carbon copy of what obtained in Europe and was thus a Department of Christian Theology, which did not reflect the totality of African realities which were religiously pluralistic. Against that background, these Departments of Theology were sectarian. And so, it should occasion no surprise that when African nations took charge of their own destinies, these Departments of Theology metamorphosed into Departments of Religious Studies (e g Ibadan, Cape Town) or Department for the Study of Religions (University of Ghana, Legon). These departments start in the conviction that while religion is a construct of the academic imagination, in reality there were several religious traditions which become the raw material for the scientific study of religion. These departments are taking seriously the religious pluralism of the society and attempting to help the network to open competently with their situations and to help forge peaceful co-existence despite the divergent truths which all these religions offer. In the words of Professor Baeta, one of the major architects of the first of this new brand of Department of Religious Studies, namely that of the University of Ghana '(In these departments) it is not religions at all that are being placed side by side under one roof ... but people, men of different faiths.' 11 This means that the metamorphosis from Theology to Religious Studies is more than a semantic question; it is saying that the Study of Religions is not mere science, but

10. 1943. Golden shore, Vol IX No 7, January: 98.

11. Baeta, C G 1971. Relationships of Christians with men of other living faiths. Accra: Ghana Universities Press, 8. 
also how human beings construct their hopes and fears in relation to ultimate reality. And, therefore, now the Study of Religion holds dialogue not only with Philosophy as in earlier days, but also with the Social Sciences. That is the significance of the rise of African Theologies and Black Theologies on the continent.

When the University of Ghana embarked on the Department for the Study of Religions, some Church leaders thought this was a betrayal of the God-talk (as Theology may be literally translated), even though the architects like C G Baeta and Noel King were committed and active churchmen and Christians. Today I am more than ever convinced that it was a step in the right direction. But this is far from saying that they are perfect. Two dangers I need to draw attention to, from my experience. First, being in a university setting, there is the constant danger of the subject becoming only a science and being accommodated to other sciences and thus losing its raison d'être as a commitment as well. Second, appointments of staff and admission of students to the departments are based solely on academic criteria and, therefore, some strange characters get into the discipline. I have no regrets that many of these students do not get ordained because of what I say of the ministry belonging to all God's people and I do witness to the good job done by at least three of my students who went into the prison services of Ghana, got to the top and really brought their God-talk to bear on their work there.

\section{Seminaries}

These have been either denominational or interdenominational. They were set up on European models and have been most conservative, sticking to the received patterns of theological education. Till today some resist the study of African philosophies. The situation is further complicated by ecclesiology exactly relevant to Africa. There are some worrying features of the situation. (a) The teachers are usually from the north. African staff often do not stay long in the seminary, often for reasons of personal advancement in church hierarchy as well as financial reasons. Rather, the churches are too eager to run up north for staff. (b) All too often the local church does not face all financial implications of the operation - it depends heavily on the churches of the north for financial support. Of course, the seminaries have produced clergy, predominantly men, who are serving faithfully in the church. But they are the first to admit that the seminary has not exactly prepared them for the ministry. I understand their comment and I do not expect it to be otherwise because most of the things we study in tertiary education are not always immediately applicable or applied in our work after college. Its value consists mainly in the discipline that enables them to introduce order into masses of facts. But the comment suggests a desire that the course in the seminary should not be only academic, but it should also be integrated with practical ministry and the hopes and fears of the peoples they go to serve. One interesting development is the linking between seminaries and university departments. The University of Ghana has worked out a system of special retationship by which two major Roman Catholic Sëmiñaries (St Peter's, Cape Coast and St Victor's Tamale), Trinity College (inter-denominational college - Anglican, 
Evangelical Presbyterian Church, Presbyterian Church, Methodist, AME Zion and one or two others), and Christian Service College, sponsored by Evangelical and some Independent African Churches, work for the degrees and diplomas of that University. The staff of the seminaries teach the courses to syllabi agreed upon between the University and the respective seminaries individually. The special relation has been good for at least two reasons: it has helped to raise the academic standards of the seminaries because the University does not only examine the candidates, but also, as a prerequisite of the relationship, approves the staff qualifications and the library facilities. And it has forced the seminaries to take seriously some non-theological disciplines such as Sociology, Philosophy and Psychology, which are useful in opening the horizons of theological students and making them more understanding of society and people. The University of Zimbabwe has a similar system, and it is a system I can recommend to the rest of Africa despite imperfections to be worked over. But alas! In some countries there is an undeclared war between university departments and seminaries, with the former oftên looking down on the latter. Obviously, the Association of Theological Schools have a job cut out for them in this area: building bridges between university departments and seminaries so as to create a community of theological educators and students who complement each other.

\section{Bible Schools}

I can do no better than quote Anza Lema's statement: 'Throughout Africa, Bible schools have long played an important role in the development of the church. Evangelists and lay preachers, so vital in mission outreach, have received their first training in these schools ... More numerous than the seminaries, they are also more accessible to the laity, especially rural areas. Their approach is less formal, and their requirements in educational standards less rigid. With few exceptions, they arc founded and run by single denominations... The training courses offered range from brief weekend programmes to training schemes of several years. The purposes for which Bible schools are used vary greatly ... Some emphasize the spiritual development of individual Christians, some the equipping of laity for ministry, and some the training of ordinands. Many combine all these three functions... As the name Bible School implies, most programmes centre on actual teaching of the Bible, the one essential textbook for their courses.' 12

I have a comment or two to make on Bible schools. They are very important to the churches. My impression is that many churches do not feel the need for highly trained personnel and, therefore, put their emphasis on Bible schools. Indeed, they tend to commit more local resources to this than to the seminaries, implying that priorities have been set in favour of Bible schools. On the other hand, a course that is heavily biblical cannot be exactly adequate for the pluralistic situation of Africa.

12. Lema, Anza 1984. Bible schools in Africa, in Directory of Theological Institutions in Africa.

Geneva: Lutheran World Federation, 20-21. 
There are some things common to the three institutions mentioned above. They tend to have rather rigid criteria for ministry and service as well as, in varying degrees, highly intellectual criteria. Dickson, in his pre-conference paper writes as follows: 'Theological education in Africa has continued to be largely residential and this has meant that only a tiny proportion of the Church's membership has opportunity to participate actively in the Church's theological development, thus accentuating the distinction between the theologically trained and the rest of the Church.' ${ }^{13}$ In that sense they have been expensive and inefficient in that they have not always answered the aspirations of the many unordained persons who yearn and look for exposure to the practices of theological education and reflection.

Against that background we now welcome approximately 100 Theological Education by Extension (TEE) programmes on the continent. In August 1986 the Conference of African Theological Institutions (CATI) and the Eastern African Association TEE organized a workshop in Mauritius to review TEE in Africa. At the meeting the following agreement was reached: 'The raison-d'être of TEE movement is to show what God can do in humanity. It is to affirm the value of man in a holistic sense. ${ }^{14}$ In practical terms it means that they adopt curricula informed by the local situation and issues raised by the context.

In reality they are different types of TEE. Some universities have Departments or Institutes of Aduit Education (University of Ghana) or Departments of Distance Learning (University of Nairobi) which have done a good job. Then there are the Church related TEE programmes. In the latter there are different catchment areas: to train the non-stipendiary or supplementary ministry (as in Zambia); to meet the theological needs of one level of theological education e $\mathrm{g}$ Christian Independency in South Africa. In Swaziland 'The Anglican Church has taken a deliberate step to open the doors to train the "whole people of God" and further that the women who will receive training will be considered for ordination as deacons. ${ }^{15}$

Now, it is all very exciting. Let me dare make a few comments on TEE.

(a) As I see them, TEE and the residential institutions are not alternatives. For education is more than stuffing people with book-knowledge; it is about forming people in community. In an Africa riddled by poverty and lack of simple resources in the average home, a residential institution has the added bonus of providing better facilities for study, e g relative comfort of room and board, electricity, etc. When residential colleges bring together peoples from different tribes, it further helps break down some of the suspicions that go with tribalism, and if they do read Theology at a university, they rub shouiders with the kinds of people they will minister to and with potential leaders of the nation which makes future relationships

13. Dickson, K A. Continuity and change in theological education. Pre-conference paper.

14. A report of the Theological Education by Extension C A T I Workshop - Mauritius 5th to 12 August 1986.

15. Ibid. 
between church and state easier. So, I do not buy the argument that it is a choice between TEE and residential colleges.

(b) TEE must be done on high academic levels and should no longer be treated as an inferior type of training; it should be treated as a valid, good structure in its own right and not as a second best. In this regard, I am glad to report it is being used more and more to train full-time ministers.

(c) Since TEE programmes are not tied down to fixed curricula, there is every possibility to explore new areas of contextual theologies. And these should be shared with the wider theological community. In this regard, let me mention the need to collect and analyse the considerable oral theology that comes from pulpits every Sunday in the villages and in the towns, which are indeed a measure of the contextual theology of the churches in Africa. What John Mbiti, Kwesi Dickson, John Marc Ela, Meinard Hebga, John Pobee or Harry Sawyerr writes on theology in Africa is only a small fraction of the body of theology on the continent; the massive volume goes unnoticed.

(d) TEE programmes also suffer from a predominance of non-African staff. If TEE is to be what it claims to be, the work and the theologizing and the structure should be planted and nurtured by native hands, so as to develop an authentic African system. The need for TEE local leadership development hardly needs to be emphasized.

(e) At the Mauritius meeting the participants stressed the need to identify learning needs and curricula of adult leaders as well as distance learning. There are whole areas where there is need for clarity to be sought by the African TEE programmes: how do the TEE initiatives respond to the needs of churches and contribute to the development of African Theology? To what extent does TEE contribute to the development of adult education, political and spiritual awarenessbuilding of the whole people of God? What is the place of the laity and women in TEE?

\section{Library and literature development}

There are quite a few theological institutions about, but in most of them a library is woefully lacking. The existing ones contain biblical-theological scholarship from the north. The need for developing authentically African theological literature is an urgent task. How do we do it? (a) Several candidates have been sponsored to do graduate degrees in the north and their theses of themes on Africa-related theological topics are still standing on library shelves and their insights not channelled back into the church life of the region. (b) The curriculum should have a course such as the University of Ghana's Department for the Study of Religions, namely viodern Theological Trends which has a large section on theological ideas being enunciated by African scholars. These courses should be seen as testing out future publications of theology from African perspectives. (c) The associations should encourage literature development. The Conference of African Institutions 
has a number of good humble beginnings: African Pastoral Studies, African Church History, African Bible Commentary. Theological journals and the development of handbooks to encourage discussions among the people of God; are also necessary.

Ideally this literature should be in the vernacular, if language is the soul of a people. But here we have an almost insoluble problem and dilemma. On the one hand, African Theology in a non-African language is a contradiction in terms. On the other hand, literature in a vernacular will be rather parochial and limited in circulation and, therefore, not a commercial proposition.

With regard to the number of languages, guesses range from two hundred to one thousand two hundred, with a mean somewhere around eight hundred. ${ }^{16}$

In my view, library and literature development is a crucial structural tool for developing Theology in the African context. But such literature should be brought into the ecumenical arena for sharing and mutual critique. By the same token Africa cannot afford to cut itself off non-African literature. Theological educators with a sound theological grounding and a sound, respectable African ideology have a role in helping to put the right foreign scholarship on the market.

\section{Theological Associations}

In the course of this presentation references have been made to associations, which are the following: Association of Central African Christian Training Institutions (ACACTI), Association of Christian Lay Centres in Africa (ACLCA), Association of Evangelicals of African and Madagascar (AEAM), Association of South African Theological Institutions (ASATI), Association des Institutions d'Enseignement Theologique en Afrique Centrale (ASTHEOL Centrale), Association des Institutions d'Enseignement Theologique en Afrique Occidentale (ASTHEOL West), Association of Theological Teachers of Madagascar (ATTM or the French FINPATEMA), West African Association of Theological Institutions (WAATI), Eastern African Association of Theological Education by Extension (EAATEE), Theological Education by Extension Associations in Nigeria (TEEAN), Organization of Independent African Churches TEE and Conference of African Theological Institutions. There are two Women's Associations: Anglophone Theological Women's Association and Francophone Theological Women's Association. There are others in the process of creation.

As I see it, the main function of these associations has been to bring together otherwise isolated institutions to confer on mutual concerns around the subject of theological education. Sometimes there is only one seminary, or even one trained New Testament scholar in a country. Through such associations, institutions and scholars have found solace and mutual strengthening. Secondly, they have turned out to be most ecumenical instruments. For, in several places, Roman Catholics join with Protestants in their associations, where in Councils of Churches, Roman 
Catholics and Protestants do not join together. In my view then, these associations have the potential to be the most effective tools of ecumenism on the African continent. If they take seriously Ecumenical Formation, we may see great ecumenical developments when ecclesial bodies will be unable to move. For those two reasons I believe the associations have a great role to play in theological as well as ecumenical development. And, of course, mention was made earlier of the associations' work vis-à-vis literature development. In an Africa short of trained personnel, such ventures can only be undertaken on a regional basis.

I have one concern. If we expect the churches to own theological education, then the associations must find ways of involving or at least engaging church leaders in their deliberations and work. The associations may not do their thing in a corner, independent of the church leaders and expect them to take them seriously. Once more Macquarie's comment quoted above is worthy of recall. The church leaders have a vision to contribute to the goals of theological education.

\section{Trained personnel}

Building and curriculum alone do not make theological education. Good teachers are an important part of the structures of theological education. The Theological Education Fund (TEF) was established out of the conviction that theological education and ministerial training are central to the life and witness of the churches. 17 Many were trained. But there is a long way to go. The experience of the Programme on Theological Education is that in Africa faculty development is a top priority If we are to arrive at the right strength of the faculty, there are a number of things we need to watch: (a) Churches must be intentional in training people for the teaching ministry and leave them there to make a 'career' of it. As was mentioned earlier, staff all too often move from colleges and thus there is no continuity. We need to learn that the teaching ministry is a respectable one in its own right. (b) Churches need to patronize the institutions in the region and not always want to send people to the north. If we continue in this, the products never get the proper African orientation and the local institutions will never develop into fully-fledged institutions of excellence for all levels of theological formation. (c) Churches need to explore and have commitment for ecumenical and regional theological institutions. Resources are not enought to have multiplicity of institutions. (d) Remuneration of faculty should also be reasonable as they go on the same markets as all others in society. (e) In December 1986 I gave a lecture at the Ecumenical Institute, Celigny on gospel and culture. During question time a student from Zaire said to me: 'We are proud of you as a distinguished African theologian, particularly for your contribution this morning. But can we develop African theology within our region when our distinguished African theologians like you are living in Europe?'

17. Lienemann-Perrin, Christine 1986. Training for a relevant ministry. Madras: The Christian Literature Society. 
African theology within our region when our distinguished African theologians like you are living in Europe?'

My response was two-fold: We need a few Africans to 'come on a "civilising mission" to Europe and America i e people who can interpret across cultures of north and south, east and west - people who have theological solidity, knowledge of cultures other than their own African culture, experience in their own Africa and wisdom. But having said that, I also concede the point of the question - such people who come north must go back to Africa to feed their ecumenical vision back into the region, particularly into church life. At what point they return must be treated seriously and prayerfully.'

\section{Funds}

Religious people are embarrassed to talk about finances. But the simple truth is that all our plans can be realized only if there are adequate financial resources. At present the funding is done in a rather haphazard way which perpetuates a dependency syndrome. Two things are necessary: long term planning and an endowment fund. Presently local churches do not sink enough of their own resources into theological education and they run north for funds and responses are largely ad hoc. What we need is a strategic giving through an endowment fund which, for about ten years, must be invested and thereafter some expenses on theological education are to be met from the interest on the endowment.

Mention of funds brings us to Ecumenical Partners and Bodies. African churches are poor, reflecting the general poverty of African societies, partly as a result of wrong priorities and as a result of their need to learn from the Independent African Churches how to generate the spirit of giving on a large scale. Partners have a tremendous contribution to make such as helping equip a few African presses, providing resources for the raw materials, especially as one African country after another has foreign exchange difficulties, and providing subsidies that will bring down the price of books for African students. However, in the long term we need Ecumenical Partners and Bodies to help us have a securer financial base. At the Accra meeting of July 1986 some of the Ecumenical Partners and Bodies were present: Institute of Missiology (Missio) (Aachen, West Germany); Evangelisches Missionswerk (Hamburg, West Germany); Church Missionary Society (London, England); Lutheran World Federation (Geneva, Switzerland); Church of Sweden Mission (Uppsala, Sweden); Presbyterian Church of the USA (New York, USA); National Council of Churches of USA and the Programme on Theological Education (Geneva, Switzerland). They joined in the debate on the future of theological education in Africa, and rightly so, if for no other reason than that which happens in theological education in Africa, the new centre of gravity of Christianity, is bound to affect churches of the North. The mutual involvement of the Ecumenical Partners and Bodies is, for me, a necessary part of describing the church as the body of Christ, a koinonia (i e a communion-fellowship). The Partners will stand with the African churches, listening to their hopes and fears, offering in humility a critique of 
affirmation. At all costs we must avoid the relationships being seen first and foremost in terms of funds. The partners may have funds to offer. But the churches and other institutions of Africa need to be clear on what they offer the world church out of their poverty. Bishop John Aglionby once wrote: 'The African has his contribution to make to the Catholic Church of Christ. His simple trustful faith, his quick response to the appeal of an enlightened conscience, his sure touch with things invisible, his natural reverence are the materials - and splendid material too - upon which can be built a nation Christian and Christlike. He is a precious stone which will one day sparkle in the crown of the King of Kings when He makes up the number of His Jewels. ${ }^{18}$ That one day may be the end of the second millennium and the churches of the north are waiting to benefit from that African precious stone.

Christianity came to Africa south of the Sahara from the north. Despite human follies, mistakes and bloody-mindedness, God has blessed the effort and now, as we face the year $2000 \mathrm{~A} \mathrm{D}$, the churches in Africa are among, if not the most bouyant. Those who believe in statistics tell us that by the year 2000 the Church in Africa will be the centre of world Christianity. Praise be to God that the seed watered and nurtured by human hands has grown into the huge tree. And when we talk about theological education, we are talking of African hands nurturing the plant in a stormy world of ideologies, different faith traditions, poverty, etc. The African churches will make it if, having received from the north, they develop their own authentically African theology and church which will go to undergird the faith. Theological education has a place in this process - to help produce persons of spiritual power, lofty aim, driving force and with clear and definite knowledge of the teachings of the Christian faith and wisdom that will enable them to preach good news of Jesus Christ to peoples through the worship of God in the beauty of holiness, drawing on what is best in African context to make the worship of God through Christ most appealing to homo africanus. Homo africanus theologizing and worshipping is digging into a treasure-store of context to engage the Word of God, and bringing their precious jewels to adorn and sparkle in the crown of the King of Kings to build a world that is Christlike. That, for me, is the ecumenical vision, gathering together all the treasures of the nations, all tongues and tribes in the Kingdom of God.

18. 1927. Golden Shore, Vol I No 7, January, 182. 